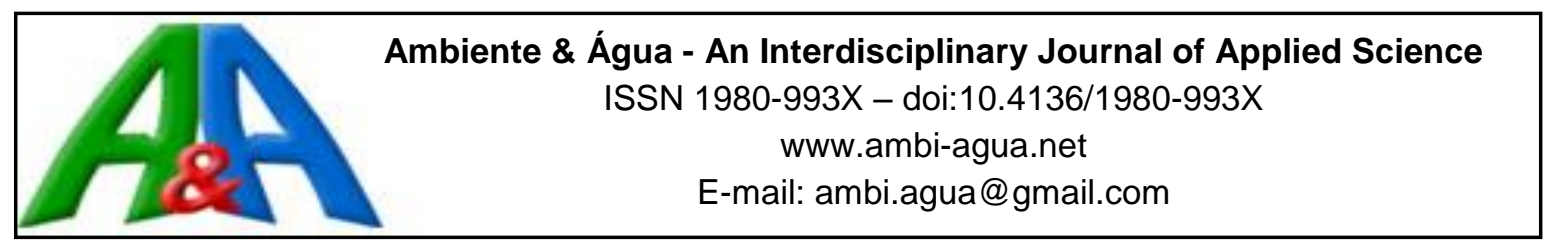

\title{
Water footprint of the Sobradinho hydropower plant, Northeastern Brazil
}

\author{
ARTICLES doi:10.4136/ambi-agua.2134
}

Received: 16 May 2017; Accepted: 06 Mar. 2018

\author{
Nayara Paula Andrade Vieira ${ }^{1 *}$; Eduardo de Oliveira Bueno ${ }^{1}$; \\ Silvio Bueno Pereira ${ }^{2}$; Carlos Rogério de Mello ${ }^{1}$ \\ ${ }^{1}$ Universidade Federal de Lavras (UFLA), Lavras, MG, Brasil \\ Departamento de Engenharia (DEF).E-mail: nayara.paula.ufla@gmail.com, \\ eobueno@yahoo.com.br,crmello@deg.ufla.br \\ ${ }^{2}$ Universidade Federal de Viçosa (UFV), Viçosa, MG, Brasil \\ Departamento de Engenharia Agrícola. E-mail: silviopereira@ufv.br \\ *Corresponding author
}

\begin{abstract}
Hydroelectricity is responsible for the greatest fraction of the electric energy generated in Brazil. The water footprint of hydropower plants (WFP) is an important indicator of the sustainable and efficient use of water resources. In this context, WFP of the Sobradinho Hydropower Plant was determined for the period from 2003 to 2012, taking into account the reservoir's historical variation for the flooded area. To accomplish this, monthly series of electric energy production, flooded area, evaporation and evapotranspiration rates were used. Average gross and net evaporation were 2,031 and 1,577 $\mathrm{mm} \mathrm{year}^{-1}$, respectively. The average power generation of this facility in the analyzed period was $462 \mathrm{MW}$, and the flooded area of its reservoir presented an average value of $3,054 \mathrm{~km}^{2}$. Based on the monthly data, the gross and net water footprints were, respectively, 417 and $325 \mathrm{~m}^{3} \mathrm{GJ}^{-1}$. Based on these results, it can be concluded that the changes in the reservoir's area exert direct and important influence on the WFP estimates of the Sobradinho hydropower plant. The WFP estimates in this study were different from other studies that adopted a constant value of $4,214 \mathrm{~km}^{2}$ for this reservoir's area, which is taken based on the normal water level of the plant operation.
\end{abstract}

Keywords: evaporation, hydroelectric dams, water consumption.

\section{Pegada hídrica da usina hidrelétrica de Sobradinho, Nordeste do Brasil}

\section{RESUMO}

A hidroeletricidade é responsável por grande parte da produção brasileira de energia elétrica. Assim, a pegada hídrica de usinas hidrelétricas apresenta-se como um importante indicador para análise e discussão de questões relacionadas ao uso sustentável e eficiente dos recursos hídricos. Nesse contexto, foi caracterizada a pegada hídrica da Usina Hidrelétrica de Sobradinho, no período de 2003 a 2012, considerando a variação histórica da área alagada pelo reservatório. Para isto, foram utilizadas séries mensais de geração, área inundada, evaporação e evapotranspiração. A evaporação bruta e líquida, médias do período de análise, foi de 2.031 e $1.577 \mathrm{~mm} \mathrm{ano}^{-1}$, respectivamente. A energia média gerada no período foi de $462 \mathrm{MW}$ médio, 
enquanto a área de inundação do reservatório apresentou um valor médio de $3.054 \mathrm{~km}^{2}$. Com base nos dados mensais estimou-se a pegada hídrica bruta e líquida em 417 e $325 \mathrm{~m}^{3} \mathrm{GJ}^{-1}$, respectivamente. A partir dos resultados pode-se concluir que a variação da área do reservatório exerce influência direta e significativa na estimativa da pegada hídrica da Usina Hidrelétrica de Sobradinho. Os valores obtidos de pegada hídrica diferem de outras estimativas que adotaram o valor constante de $4.214 \mathrm{~km}^{2}$, correspondente a área do reservatório no nível d'água normal de operação da usina.

Palavras-chave: consumo de água, evaporação, hidrelétrica.

\section{INTRODUCTION}

Hydroelectric power plants (HPPs) have accounted for up to $65 \%$ of electric energy production in Brazil. Studies that address the relationship between water and hydroelectricity generation have been increasingly required because of the growing concern regarding the water sustainability of hydropower plants (Coelho et al., 2017).

The volume of water in the reservoirs lost by evaporation results in loss of electric energy generation in cascade hydropower plants, in addition to the negative impacts on the allocation of water resources. The evaluation of the effectiveness of the water resources is therefore extremely important. According to Hoekstra et al. (2011), water footprint (WFP) is an indicator of the efficiency of the use of water resources, as it can quantify the total water consumption of a production chain.

Mekonnen and Hoekstra (2011) classified WFP as: i) green water footprint ("green water"), which refers to the volume of rainwater consumed during the production process, being more relevant to agricultural and forestry products; ii) gray water footprint ("gray water"), that indicates the level of freshwater pollution associated with the production process; and iii) blue water footprint ("blue water"), that is related to the consumption of surface or underground freshwater. The WFP of HPPs is included in the last category.

The HPP's water footprint considers how much water is annually lost from a reservoir's evaporation for a given annual electric energy production, being highly dependent on climatic, topographical, hydrological and technological factors, rendering it specific to each plant (Mekonnen and Hoekstra, 2011).

The water footprint is directly proportional to evaporation; that is, the greater evaporation, the greater the WFP. Therefore, both the surface area of the reservoir and weather conditions, such as air temperature and solar radiation, directly influence the evaporation (Bueno et al., 2016). In general, hydropower plants have been characterized by a high water footprint, especially in the tropical and subtropical regions, because the water losses by evaporation is higher than in the temperate regions (Bueno and Mello, 2015).

The São Francisco River Basin encompasses the states of Minas Gerais, Bahia, Goias, Pernambuco, Sergipe and Alagoas, and carries around 64.4 billion $\mathrm{m}^{3}$ of water annually to the semi-arid region of northeastern Brazil, besides hydroelectric energy generation. Water availability of the São Francisco River corresponds to $69 \%$ of the surface water in the Northeast Brazil and presents an accumulated potential of 50.9 billion $\mathrm{m}^{3}$ per year. There are many hydroelectric plants in the basin, including Três Marias, Sobradinho, Itaparica, Moxotó, Paulo Afonso and Xingó. The total hydroelectric potential available in this basin is approximately 26,320 MW, and the Sobradinho plant solely presents an installed power capacity of 1,050 MW (CODEVASF, 2004).

The Sobradinho HPP reservoir is one of the largest surface waters in the world, and regulates water flows in the São Francisco River Basin, providing water to maintain the downstream hydropower plants. According to Vieira et al. (2016), the average yearly 
evaporation of the reservoir is of $2,108 \mathrm{~mm}$, which is equivalent to an average flow of $203 \mathrm{~m}^{3} \mathrm{~s}^{-1}$.

The flooded area of the Sobradinho HPP reservoir corresponds to the normal water level of the plant $(392.50 \mathrm{~m})$ and is defined as $4,214 \mathrm{~km}^{2}$. This value has been taken into consideration in studies related to this plant, including those related to the water footprint. However, according to the long-term daily measurements of operating levels of the reservoir (from 1979 to 2012 , totaling 34 years), the actual average flooded area is $3,062 \mathrm{~km}^{2}$. This significant difference in relation to the average flooded area provided in the design of the plant has strongly influenced the evaporation rates, which leads to inaccurate WFP estimates.

The objective of this study was to refine the water footprint characterization of the Sobradinho HPP using the historical variations of the flooded area of the reservoir, instead of the average value which has been considered in other studies.

\section{MATERIALS AND METHODS}

\subsection{Study area}

The São Francisco River has its sources in the Canastra Range region in Minas Gerais state, and flows through the states of Minas Gerais, Bahia, Goias, Pernambuco, Sergipe and Alagoas, and the Federal District. The main hydropower plants installed in the São Francisco River are Três Marias, Sobradinho, Itaparica, Moxotó, Paulo Afonso and Xingó (Pereira et al., 2009).

The Sobradinho Reservoir is located in the sub-medium region of the São Francisco Basin near Sobradinho County, Bahia, and approximately $40 \mathrm{~km}$ upstream from the cities of Juazeiro (Bahia) and Petrolina (Pernambuco). The Sobradinho hydropower plant (HPP) has an important role in electric energy generation along with water flow regulation for entire the basin (Vieira, 2015).

According to the São Francisco Hydroelectric Company (CHESF, 2014), the reservoir storage capacity is 34 thousand cubic hectometers, regularizing a flow rate of $2,060 \mathrm{~m}^{3} \mathrm{~s}^{-1}$. The Sobradinho HPP construction started in 1973 and began operation in 1979, with an installed power of 1,050 MW.

The climate-types of the Sobradinho Reservoir region are arid and semi-arid, classified as BSh according to Köppen climate, with high temperatures and low precipitation. The average annual climate indicators are: precipitation (from 300 to $800 \mathrm{~mm}$ ); temperature $\left(27^{\circ} \mathrm{C}\right)$; total annual insolation (2,800 hours), and potential evapotranspiration $(1,550 \mathrm{~mm})$ (CODEVASF, 2004).

\subsection{Water footprint estimation for the hydroelectric generation}

The calculation of the water footprint (WFP) of the Sobradinho HPP was performed using the definition of Mekonnen and Hoekstra (2012), which is based on monthly evaporation, evapotranspiration and electric energy generation. Thus, two approaches were considered, Gross WFP and Net WFP, which were calculated using Equations 1 and 2, respectively:

Gross $W F=\frac{E o}{H}$

Net $W F=\frac{(\text { Eo-Etr })}{H}$

Where, WFP is the water footprint $\left(\mathrm{m}^{3} \mathrm{GJ}^{-1}\right), \mathrm{H}$ is the annual electric energy production (GJ year ${ }^{-1}$ ), Eo is the annual volume of evaporation $\left(\mathrm{m}^{3}\right.$ year $\left.{ }^{-1}\right)$, obtained by the product of the evaporated quantity $\left(\mathrm{m}_{\text {year }}{ }^{-1}\right)$ and the reservoir's area $\left(\mathrm{m}^{2}\right)$, and ETr is actual annual volume of evapotranspiration of the flooded area $\left(\mathrm{m}^{3}\right.$ year $\left.{ }^{-1}\right)$, that is, the volume of water that would naturally evaporate without the existence of the reservoir.

\section{IPABH}

Rev. Ambient. Água vol. 13 n. 3, e2134 - Taubaté 2018 
The monthly electric power datasets applied in the study correspond to the period from 2003 to 2012, and were provided by the Brazilian Electricity Regulatory Agency (ANEEL, 2015). They are presented in Figure 1.

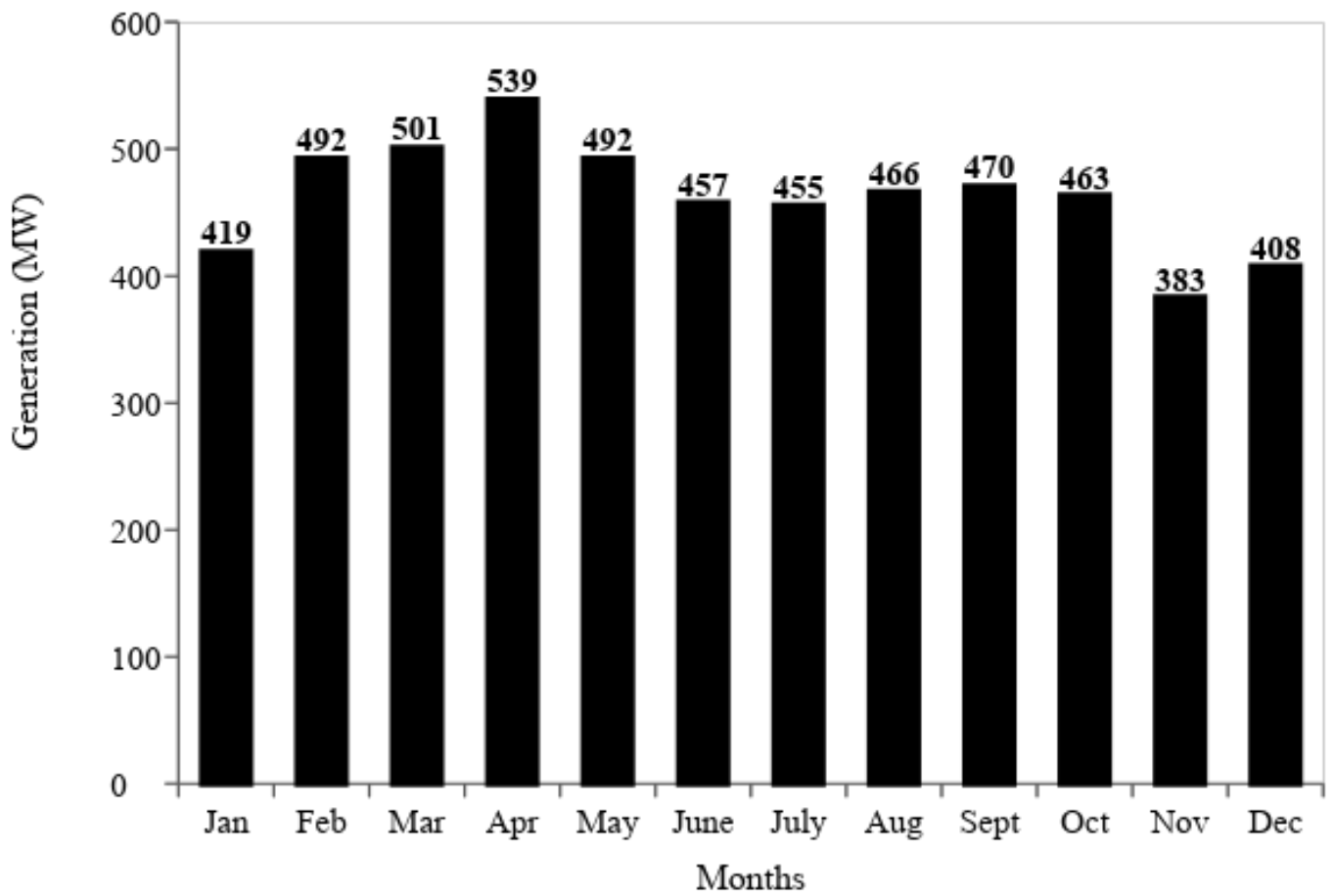

Figure 1. Monthly average power generation of the Sobradinho HPP for the period from 2003 to 2012.

By analyzing the historical data series of generation, it was verified that during the period known as "blackout of the electric sector" (years 2001 and 2002) the average power generation in 2001 was only $295 \mathrm{MW}$, much lower than the average of the period under study (462 MW). In recent years of water shortage, the annual power generation averages reached $255 \mathrm{MW}$ in 2014 and 192 MW in 2015, the lowest observed power generation since the beginning of operation of the plant.

The monthly series of evaporation (Eo) of the Sobradinho Reservoir were obtained from Vieira (2015), who applied the Penman method. The average annual evaporation of the period from 2003 to 2012 was equal to 2,031 mm (Figure 2A).

The lowest evaporation rate was observed for May and June while the highest was observed for October. According to Vieira et al. (2016), the evaporation peak in October is explained based on the highest insolation, temperature and wind speed, associated with the low precipitation rate in the region.

To calculate the net evaporation for the Sobradinho HPP, it was necessary to estimate the actual evapotranspiration (ETr) of the area that was flooded by the reservoir. Climatological water balance (CWB) proposed by Thorntwaite and Mather (1955), was used to calculate ETr, and the potential evapotranspiration estimation (ETp) was performed with the equation proposed by the same authors. The monthly data of average air temperature and precipitation were obtained from Vieira (2015).

The monthly distribution of the actual evapotranspiration can be observed in Figure 2A. For Sobradinho Reservoir, ETr is limited by the precipitation amount since ETp is much higher than precipitation, which provokes a water deficit in all the months of the year. The estimated annual evapotranspiration was $457 \mathrm{~mm}_{\text {year }}{ }^{-1}$. 


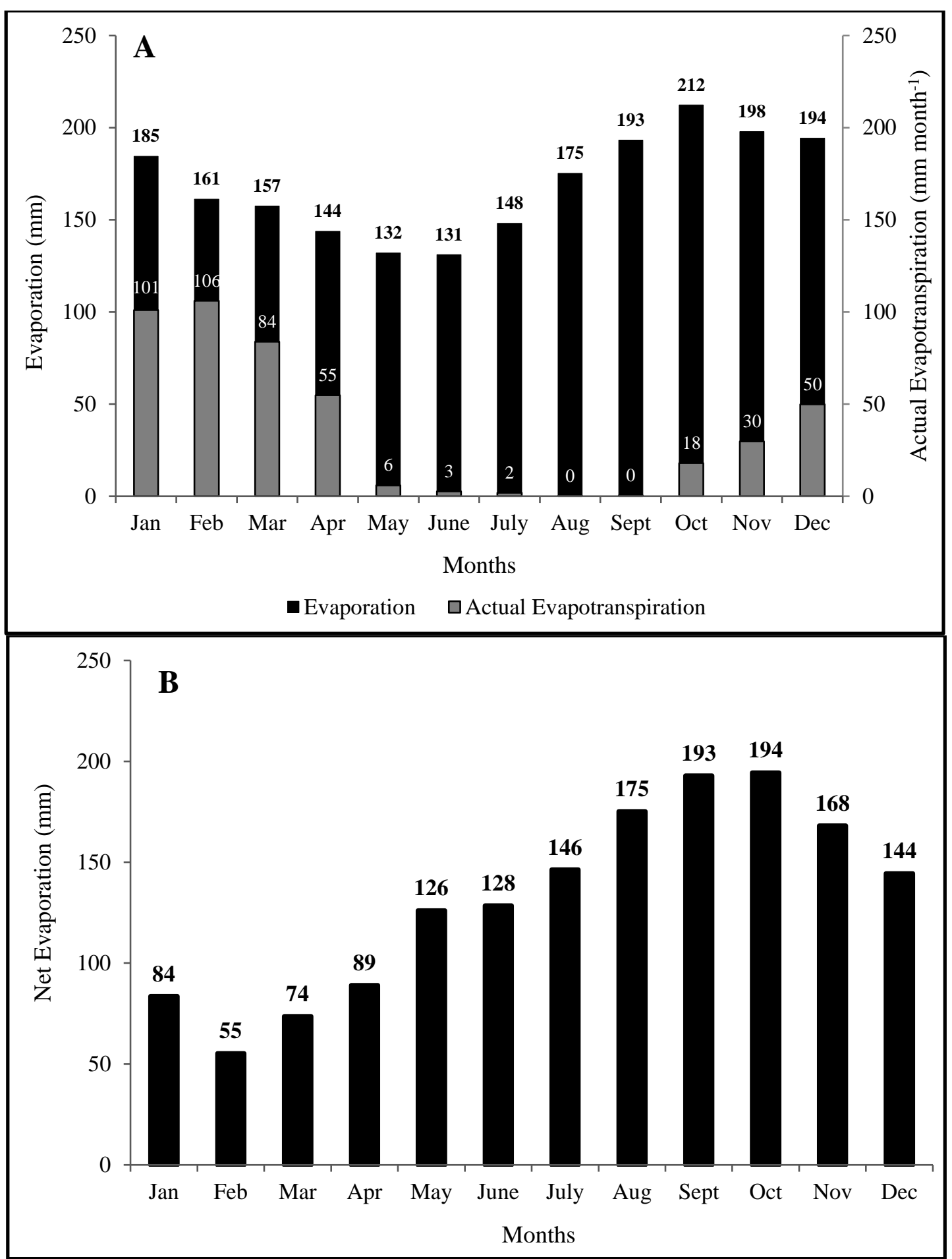

Figure 2. Monthly average evaporation of the Sobradinho Reservoir and evapotranspiration of the flooded area estimated based on the Thornthwaite and Mather climatological water balance (A), and monthly net evaporation of the Sobradinho Reservoir (B).

Based on both monthly evaporation (Eo) and actual evapotranspiration (Etr), it was possible to estimate the net evaporation of the reservoir subtracting Etr from Eo. The monthly variation of the net evaporation is presented in Figure $2 \mathrm{~B}$, and its annual total was about $1,577 \mathrm{~mm}_{\text {year }}{ }^{-1}$. By analyzing the behavior of the net evaporation, it can be seen that the highest estimated value was obtained in October due to the combination of high evaporation and low actual evapotranspiration. The lowest net evaporation was estimated for February,

\section{IPABH}


since the highest precipitation amount observed in this month increases the real evapotranspiration.

As pointed out, unlike other studies that adopted a fixed water surface of $4,214 \mathrm{~km}^{2}$ for the Sobradinho Reservoir to estimate the evaporated water volume, this study considered the monthly variation of the flooded area. Flooded area data were provided by Chesf, and the monthly averages throughout the studied period can be seen in Figure 3. Larger water surfaces were observed for April and May and smaller ones were verified for November and December. The flooded area of the Sobradinho Reservoir showed an average value of 3,054 $\mathrm{km}^{2}$ during the studied period.

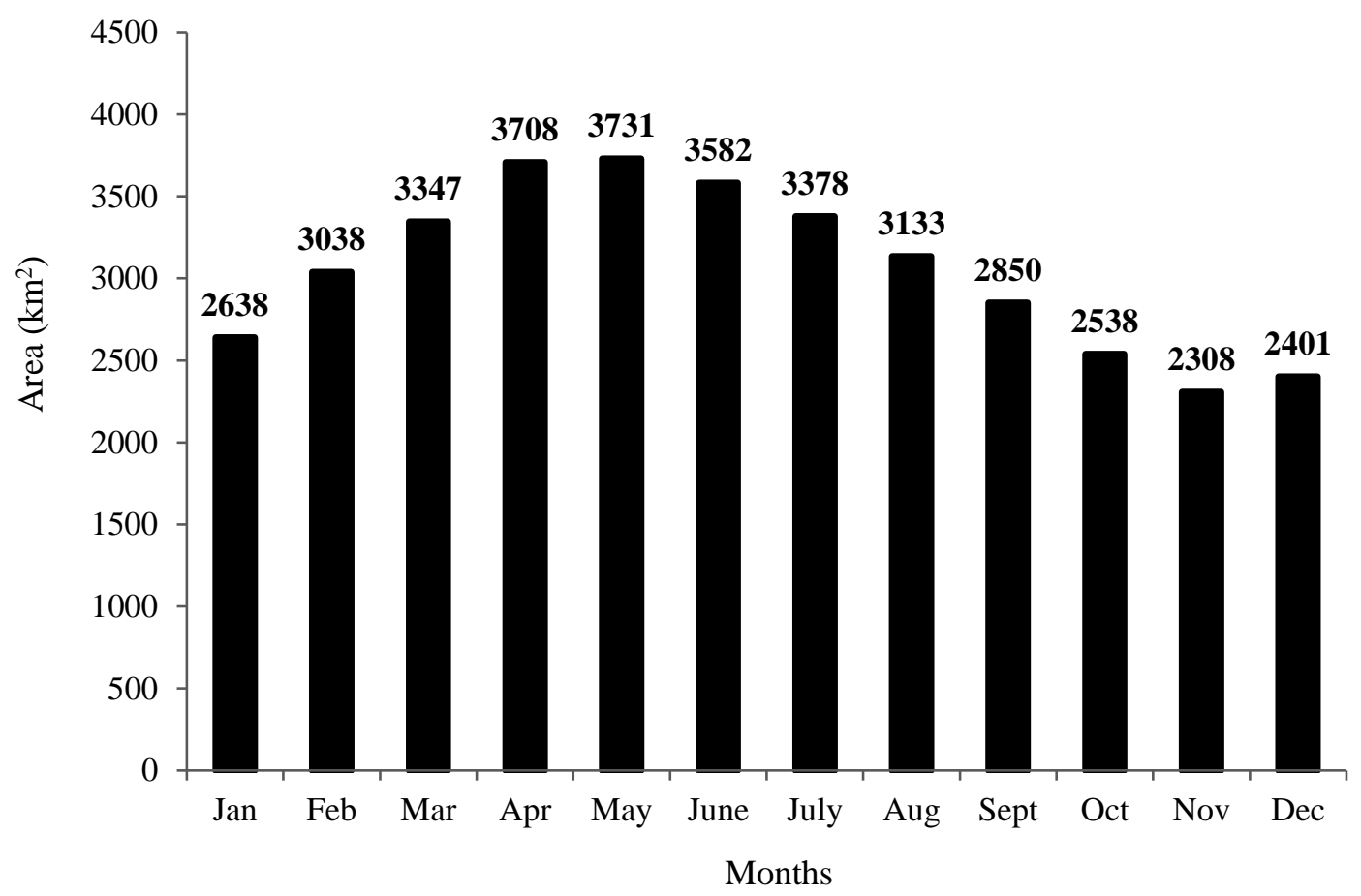

Figure 3. Monthly average area of the Sobradinho Reservoir (in $\mathrm{km}^{2}$ ) throughout the studied period (from 2003 to 2012).

For Mekonnen and Hoekstra (2011), the relationship between the surface of the reservoir and the installed capacity of the hydropower plant has a greater impact on the estimation of the water footprint than weather conditions (evaporation). The flooded area and the installed capacity reflects a linear and positive relationship with the WFP for the Sobradinho HPP. In general, hydropower plants that flood large areas per unit of installed power capacity present a higher WFP than those which flood small areas per unit of installed power capacity. The average relationship between the flooded area and the power generated by the Sobradinho HPP during the studied period was 659 ha $\mathrm{MW}^{-1}$.

\section{RESULTS AND DISCUSSION}

WFP evaluation was performed considering evaporation and electric energy generation simultaneously, since both variables influence its calculation in opposite ways. The greater the evaporation, the greater the WFP for a given electric energy production and the higher the power generation, the lower the WFP, whereas there is no increase in evaporation.

In general, the sensitivity result of the Gross WFP of Sobradinho HPP was higher regarding the variation of electric energy generation than regarding the variation of the losses by 
evaporation. However, Net WFP estimated was more sensitive to the net evaporation (difference between evaporation and actual evapotranspiration), and less sensitive to the seasonality of electric energy generation. On the monthly scale, the variability of the electric energy produced by Sobradinho HPP was much lower than the variability of net evaporation. As the climate of the region is arid/semi-arid, potential evapotranspiration exceeds precipitation, which causes a pronounced water deficit in the Sobradinho region. Therefore, ETr is limited by the amount of rain, since it cannot surpass the precipitation in the region (Pereira et al. 2009), which restricts the application of the CWB method in this region. As the monthly amount of precipitation is strongly influenced by seasonality, the CWB method applied in arid and semi-arid regions trends to generate results roughly in relation to the physical reality. Thus, the ETr will present important seasonality, culminating in strong variation in the net evaporation throughout the year.

Regarding Gross WFP and Net WFP estimates for the Sobradinho HPP, the difference between them ( $\triangle \mathrm{WFP})$ as well as the respective monthly averages of gross and net evaporation can be found in Table 1. Figure 4 shows the monthly distribution of both Gross WFP and Net WFP for Sobradinho HPP throughout the year.

Table 1. Estimation of the gross and net WFP for Sobradinho HPP throughout studied the period.

\begin{tabular}{|c|c|c|c|c|c|c|}
\hline Month & Average Generation & Gross Evaporation & Net Evaporation & Gross WF & Net WF & $\Delta \mathbf{W F}$ \\
\hline & (GJ) & \multicolumn{2}{|c|}{$\left(\mathrm{m}^{3}\right.$ month $\left.^{-1}\right)$} & \multicolumn{3}{|c|}{$\left(\mathrm{m}^{3} \mathbf{G J}^{-1}\right)$} \\
\hline Jan & $1,121,782$ & $495,781,787$ & $229,315,116$ & 442 & 204 & 238 \\
\hline $\mathrm{Feb}$ & $1,200,240$ & $489,120,781$ & $167,046,978$ & 408 & 139 & 268 \\
\hline Mar & $1,341,411$ & $525,897,057$ & $245,419,468$ & 392 & 183 & 209 \\
\hline Apr & $1,396,747$ & $532,536,227$ & $329,354,960$ & 381 & 236 & 145 \\
\hline May & $1,317,996$ & $491,813,012$ & $469,801,944$ & 373 & 356 & 17 \\
\hline June & $1,185,688$ & $468,516,619$ & $459,202,265$ & 395 & 387 & 8 \\
\hline July & $1,218,786$ & $501,853,866$ & $495,773,730$ & 412 & 407 & 5 \\
\hline Aug & $1,248,455$ & $549,065,236$ & $549,065,226$ & 440 & 440 & 0 \\
\hline Sept & $1,219,380$ & $550,323,772$ & $549,183,624$ & 451 & 450 & 1 \\
\hline Oct & $1,240,575$ & $535,704,135$ & $490,276,583$ & 432 & 395 & 37 \\
\hline Nov & 992,457 & $453,932,815$ & $385,145,892$ & 457 & 388 & 69 \\
\hline Dec & $1,091,830$ & $461,242,568$ & $341,673,216$ & 422 & 313 & 110 \\
\hline
\end{tabular}

The lowest Gross WF was obtained for the month of May, due to the lower evaporation rate of the reservoir and greater electric energy generation at Sobradinho HPP, reaching the maximum value in November under the influence of the highest evaporation and, mainly, of the lowest electric energy generation (Figure 1). The average annual Gross WF for the studied period was $417 \mathrm{~m}^{3} \mathrm{GJ}^{-1}$.

In February, the lowest Net WF was obtained for the Sobradinho HPP due to the high electric energy generation, and mostly to the lowest estimate of the net evaporation (as a result of the high actual evapotranspiration). In September, the Net WF reached the highest value due to the high evaporation and to the very low actual evapotranspiration, resulting in a significant net evaporation. The average annual Net WF for the studied period was $325 \mathrm{~m}^{3} \mathrm{GJ}^{-1}$. 


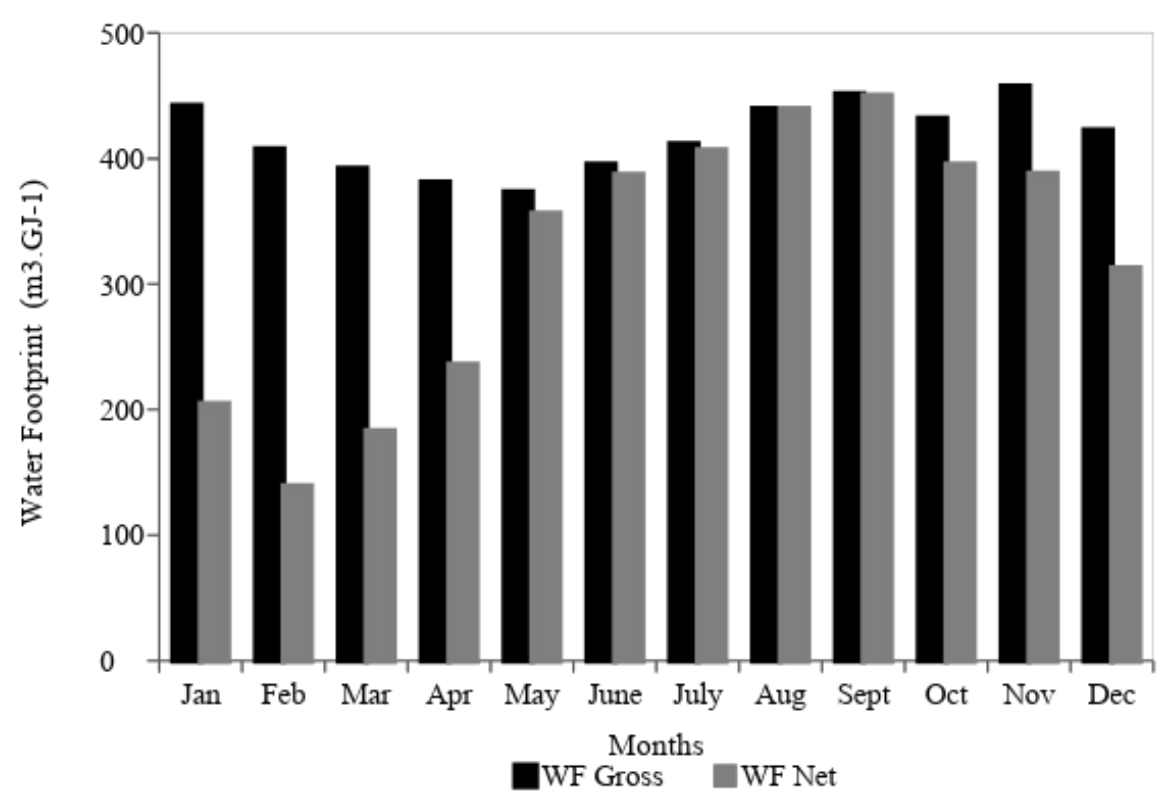

Figure 4. Average gross and net water footprint for Sobradinho HPP throughout the studied period (2003 to 2012).

\subsection{Comparison of the water footprint of the Sobradinho HPP with other studies}

Mekonnen and Hoekstra (2011) estimated a Gross WFP of $399 \mathrm{~m}^{3} \mathrm{GJ}^{-1}$ for Sobradinho HPP. In their study, the calculation of evapotranspiration was carried out by means of the Penman-Monteith equation using meteorological datasets observed at the Petrolina (PE) weather station for the period between 1996 and 2005. They estimated a high evaporation rate $\left(2,841 \mathrm{~mm}\right.$ year $\left.^{-1}\right)$ along with high power generation $\left(950 \mathrm{MW}\right.$ year $\left.{ }^{-1}\right)$ and fixed the flooded area $\left(4,214 \mathrm{~km}^{2}\right)$ for the WFP calculation.

Ferreira and Firmo (2015) estimated a Gross WFP for Sobradinho HPP of $796 \mathrm{~m}^{3} \mathrm{GJ}^{-1}$ and $615 \mathrm{~m}^{3} \mathrm{GJ}^{-1}$ for Net WFP. The power generation adopted in the cited study was the average from 1994 to 2014, according to ANEEL (2015) (479 MW). Gross and net reservoir evaporation rates were calculated from the Brazilian National Electrical System Operator (ONS, 2004), being, respectively, 2,521 and 1,946 $\mathrm{mm} \mathrm{year}^{-1}$. The flooded area also was considered fixed, and equal to $4,196 \mathrm{~km}^{2}$ (ONS, 2015)

Bueno and Mello (2015) estimated a WFP for Sobradinho HPP of $555 \mathrm{~m}^{3} \mathrm{GJ}^{-1}$ and $326 \mathrm{~m}^{3} \mathrm{GJ}^{-1}$, respectively, for the Gross WFP and Net WFP methods. The power generation considered in their study was the average from 2010 to 2012 obtained from ANEEL (2015), and equal to $460 \mathrm{MW}$. The surface water of the reservoir was also fixed and equal to $4,214 \mathrm{~km}^{2}$, corresponding to the normal operation of the facility. The authors estimated the evaporation of the reservoir and the real evapotranspiration of the flooded area using the computer program SisEvapo v2.0 - System to Calculate the Net Evaporation of the Reservoirs of the Brazilian Electric System, adopted by the ONS. This computer system is based on the Complementary Relationship Lake Evaporation (CRLE) and Complementary Relationship Area Evapotranspiration - (CRAE) Models, both proposed by Morton (1983). The dataset used was the climatological normal of the National Institute of Meteorology (INMET), which covers the period from 1961 to 1990 . The average evaporation considered to estimate Gross WFP was $1,909 \mathrm{~mm}$ year $^{-1}$, and for the Net WFP, $1,121 \mathrm{~mm} \mathrm{year}^{-1}$.

\subsection{Main sources of errors in the WFP estimation for hydropower plants}

The WFP studies for hydropower plants (Mekonnen and Hoekstra, 2011; Ferreira and Firmo, 2015; Bueno and Mello, 2015) in general have adopted a fixed flooded area which corresponds to the normal operating level of the plant $\left(4,214 \mathrm{~km}^{2}\right.$ for Sobradinho HPP). In this 
study, we could observe that the design average flooded area is significantly greater than the actual area flooded by the reservoir (average of 3,062 $\mathrm{km}^{2}$ ), according to the long-term daily water level monitoring provided by Chesf (34 years).

This difference in flooded area generates significant errors in the volume of the evaporated water and, consequently, in WFP estimation. For example, considering the average of both evaporation and electric energy produced by the Sobradinho HPP, it was observed that an error of $1,000 \mathrm{~km}^{2}$ in the flooded area would result in an overestimation of $33 \%\left(139 \mathrm{~m}^{3} \mathrm{GJ}^{-1}\right)$ of the Gross WFP of this facility.

Besides the flooded area, errors in the evaporation estimates can also provoke errors in the WFP estimates. In the case of the Sobradinho HPP, the studies of Mekonnen and Hoekstra (2011) and Ferreira and Firmo (2015) estimated evaporation rate values much higher than the estimated ones in the present study and by the Bueno and Mello (2015) study as well. Therefore, considering the average of both generation and flooded area in the studied period, an error of $500 \mathrm{~mm}$ in the annual evaporation would result in an overestimate of $25 \%\left(105 \mathrm{~m}^{3} \mathrm{GJ}^{-1}\right)$ of the Gross WFP of the Sobradinho HPP.

Finally, as the greater electric energy production the smaller WFP, errors in the electric energy production will also impact the WFP estimation. In this sense, we observed that for the Sobradinho HPP, considering the average of both evaporation and the flooded area, an error of $\pm 100 \mathrm{MW}$ in the annual average power generation would result in errors in the gross WFP of $\pm 30 \%\left( \pm 126 \mathrm{~m}^{3} \mathrm{GJ}^{-1}\right)$. It should be noted that Mekonnen and Hoekstra (2011) adopted a high power generation (950 MW year ${ }^{-1}$ ) for the Sobradinho HPP in their WFP calculation, while in the present study and in others such as Ferreira and Firmo (2015) and Bueno and Mello (2015), the power generation considered were near and lower than $467 \mathrm{MW}$.

The above considerations are also valid for an analysis of errors in the estimation of the net water footprint of hydropower plants.

\section{CONCLUSIONS}

It was possible to refine the water footprint characterization for the Sobradinho HPP due to a more precise evaporation estimation method, and consideration of the fluctuations in the flooded area of the reservoir during the period from 2003 to 2012, as historically the flooded area rarely reached the designed value (normal operating level) of the plant.

The Gross and Net WFP of the Sobradinho HPP were estimated at 417 and $325 \mathrm{~m}^{3} \mathrm{GJ}^{-1}$, respectively, a difference of $28 \%$ between the procedures.

Different WFP results regarding other studies carried out on the Sobradinho HPP were also found, which may be justified by the differences in the evaporation values, power generation and, mainly, the flooded area.

\section{REFERENCES}

AGÊNCIA NACIONAL DE ENERGIA ELÉTRICA - ANEEL (Brasil). Compensação Financeira Pela Utilização de Recursos Hídricos. Histórico da Geração. Disponível em: http://www.aneel.gov.br/aplicacoes/cmpf/gerencial/. Acesso em: 20 jan, 2015.

BUENO, E. O.; MELLO, C. R. Pegada hídrica de usinas hidrelétricas. In SIMPÓSIO BRASILEIRO DE RECURSOS HÍDRICOS, 21., 22-27 Nov, 2015, Brasília.++ Anais... Brasília: ABRH, 2015. p. 1-9.

BUENO, E. O.; MELLO, C. R.; ALVES, G. J. Evaporation from Camargos hydropower plant reservoir: water footprint characterization. Revista Brasileira de Recursos hídricos, Porto Alegre, v. 21, n. 3, p. 570-575, 2016. http://dx.doi.org/10.1590/23180331.011616021 
COELHO, C. D.; SILVA, D. D. da; SEDYAMA, G. C.; MOREIRA, M. C.; PEREIRA, S. B.; LANA, Â. M. Q. Comparison of the water footprint of two hydropower plants in the Tocantins river of Brazil. Journal of Cleaner Production, v. 153, p. 164-175, 2017. http://dx.doi.org/10.1016/j.jclepro.2017.03.088

COMPANHIA HIDROELÉTRICA DO SÃO FRANCISCO - CHESF. Fichas Técnicas das usinas da região Nordeste. Disponível em:https://goo.gl/JHT8YL. Acesso em: 20 fev. 2014.

COMPANHIA DE DESENVOLVIMENTO DO VALE DO SÃO FRANCISCO E DO PARNAÍBA - CODEVASF. Potenciais energéticos. 2004. Disponível em: http://www.codevasf.gov.br/. Acesso em: 10 fev. 2014.

FERREIRA, F. F.; FIRMO, H. T. Pegada Hídrica de Hidroeletricidade no Brasil. In CONGRESSO BRASILEIRO DE ENERGIA, 16., 20-22 Out, 2015, Rio de Janeiro. Anais... Rio de Janeiro, $2015 . \quad$ Disponível em: http://www.congressoenergia.com.br/trabalho.html. Acesso em: 05 out. 2016.

HOEKSTRA, A. Y.; CHAPAGAIN, A. K.; ALADAYA, M. M. Manual de avaliação da pegada hídrica: estabelecendo o padrão global. São Paulo: Water Footprint Network, 2011. $191 \mathrm{p}$.

MEKONNEN, M. M.; HOEKSTRA, A. Y. The blue water footprint of electricity from hydropower. Hydrology and Earth System Sciences, v. 16, p. 179-187, 2012.

MEKONNEN, M. M.; HOEKSTRA, A. Y. The water footprint of electricity from hydropower. Delft: UNESCO-IHE, 2011. 36 p. (Value of Water Research Report Series, 51).

MORTON, F. I. Operational estimates of lake evaporation. Journal of hydrology, v. 66, p. 77100, 1983.

OPERADOR NACIONAL DO SISTEMA ELÉTRICO - ONS (Brasil). Evaporações líquidas nas usinas hidrelétricas. Rio de Janeiro, 2004. 61 p.

OPERADOR NACIONAL DO SISTEMA ELÉTRICO - ONS (Brasil). Diagrama esquemático das usinas hidrelétricas do sistema interligado nacional - SIN. Janeiro de 2015. Disponível em: https://goo.gl/pU7yxF

PEREIRA, S. B.; PRUSKI, F. F.; SILVA, D. D.; RAMOS, M. M. Evaporação líquida no lago de Sobradinho e impactos no escoamento devido à construção do reservatório. Revista Brasileira de Engenharia Agrícola e Ambiental, v. 13, n. 3, p. 346-352, 2009. http://dx.doi.org/10.1590/S1415-43662009000300018

THORNTHWAITE, C. W.; MATHER, J. R. The water balance. Publications in Climatology. New Jersey: Drexel Institute of Technology,1955. 104 p.

VIEIRA, N. P. A. Estimativa da evaporação nos reservatórios de Três Marias - MG e Sobradinho - BA. 2015. 82 f. Dissertação (Mestrado em Engenharia Agrícola) Universidade Federal de Viçosa, Viçosa, 2015.

VIEIRA, N. P. A.; PEREIRA, S. B.; MARTINEZ, M. A.; SILVA, D. D. da; SILVA, F. B. Estimativa da evaporação nos reservatórios de Sobradinho e Três Marias usando diferentes modelos. Engenharia Agrícola, v. 36, n. 3, p. 433-448, 2016. http://dx.doi.org/10.1590/1809-4430-Eng.Agric.v36n3p433-448/2016 